\title{
Fermentation Conditions and Media Optimization for Isocitric Acid Production from Ethanol by Yarrowia lipolytica
}

\author{
Svetlana V. Kamzolova ${ }^{1},{ }^{1}$ Roman V. Shamin, ${ }^{2,3}$ \\ Nadezda N. Stepanova, ${ }^{1}$ Grigorii I. Morgunov, ${ }^{2}$ Julia N. Lunina, ${ }^{1}$ Ramil K. Allayarov, ${ }^{1}$ \\ Vladimir A. Samoilenko, ${ }^{1}$ and Igor G. Morgunov ${ }^{1}$ \\ ${ }^{1}$ G.K. Skryabin Institute of Biochemistry and Physiology of Microorganisms, Russian Academy of Sciences, Pr-t Nauki 5, \\ P.O. Box 142290, Pushchino, Moscow, Russia \\ ${ }^{2}$ Peoples' Friendship University of Russia (RUDN University), Miklukho-Maklaya Str. 6, P.O. Box 117198, Moscow, Russia \\ ${ }^{3}$ Moscow Technological University (MIREA), Vernadskogo Pr. 78, P.O. Box 119454, Moscow, Russia \\ Correspondence should be addressed to Svetlana V. Kamzolova; kamzolova@rambler.ru
}

Received 29 September 2017; Revised 18 December 2017; Accepted 10 January 2018; Published 7 February 2018

Academic Editor: Isabelle Chevalot

Copyright (C) 2018 Svetlana V. Kamzolova et al. This is an open access article distributed under the Creative Commons Attribution License, which permits unrestricted use, distribution, and reproduction in any medium, provided the original work is properly cited.

\begin{abstract}
Isocitric acid exists in the form of four stereoisomers, of which only the threo-Ds-form (ICA) is a natural active compound, an intermediate of Krebs cycle, and suitable for nutritional and pharmaceutical use. In this paper, we propose a method for ICA production from ethanol by yeast Yarrowia lipolytica. The effects of temperature, $\mathrm{pH}$ of the medium, and aeration on the growth of the producer Y. lipolytica VKM Y-2373 and synthesis of ICA were studied. An optimal fermentation regime, which ensures a good growth of the producer and directed synthesis of the target product, was determined. The producer is advised to carry out cultivation at $29^{\circ} \mathrm{C}$ and various $\mathrm{pH}$ of the medium and the oxygen concentration $\left(\mathrm{pH} 5\right.$ and $\mathrm{pO}_{2} 20-25 \%$ (of saturation) during the growth period and $\mathrm{pH} 6$ and $\mathrm{pO}_{2} 50-55 \%$ (of saturation) during the acid formation) on a nutrient medium containing an increased content of zinc $(0.6 \mathrm{mg} / \mathrm{L})$, iron $(1.2 \mathrm{mg} / \mathrm{L})$, and $30 \mathrm{mM}$ itaconic acid (inhibitor of isocitrate lyase-the key enzyme of ICA metabolism) should also be introduced into the nutrition medium. Such fermentation production mode provides $90.5 \mathrm{~g} / \mathrm{L}$ ICA with process selectivity of $80 \%$, mass yield $\left(Y_{\text {ICA }}\right)$ of $0.77 \mathrm{~g} / \mathrm{g}$, and energy yield $\left(\eta_{\text {ICA }}\right)$ of $0.278 \mathrm{~g} / \mathrm{g}$.
\end{abstract}

\section{Introduction}

It is well known that the target of hypoxia is aerobic energy metabolism, occurring in mitochondria [1-8]. The authors of the mentioned article reported that during hypoxia the supply of oxygen is greatly disturbed, and the hypoxic conditions of various disease severities are developed. As a consequence, the protective mechanisms (stress reactions), mobilizing the energy resources and structural body, and activating the circulatory and respiratory functions are included in humans. The operation of such reactions is associated with the sharp increase in energy consumption. Excessive or prolonged stress reactions are accompanied by a progressive depletion of the body, which in turn leads to pathological changes of internal organs and tissues. In these circumstances, the development of pharmaceutical agents, (1) to increase the body's resistance to the influence of stress and hypoxic factors, (2) to maximize the use of oxygen supply in the body, (3) to increase the production of energy substrates, and (4) to protect the internal organs from pathological changes, becomes relevant. We suggested that the Krebs cycle intermediate, isocitric acid, can contribute to the normalization of energy metabolism, the adaptation to adverse environmental conditions, to stimulating physical performance, to preventing the development of fatigue, and to protecting the internal organs and tissues from hypoxic factors. Isocitric acid is the only metabolite of the Krebs cycle that can unblock succinate dehydrogenase and, hence, promote cell respiration even at durable and intense stresses [9]. In this case, cell respiration 
is probably not increased. Presumably, isocitric acid merely promotes the utilization of oxygen available in cells.

The bottleneck in the development and practical application of this simple, nontoxic, and moderately priced preparation is the absence of industrial production of isocitric acid of required quality, which is different from the products of chemical synthesis by natural isomeric composition. It is known that the presence of even small impurities in the chemically produced preparations decreases the quality of preparations and makes them toxic for plants, animals, and humans [10-12]. It should be noted that isocitric acid has four isomers: erythro-Ds, erythro-Ls, threo-Ls, and threo-Ds. Among these isomers, only threo-Ds-isocitric acid (ICA) is a natural compound, which is present in every living cell [13] and, hence, only this isomer is of practical interest for food and medicine. ICA sources include the leaves and stems of some plants, fruits, and berries, especially in Hylotelephium spectabile (syn. Sedum spectabile); however, the ICA content of these substrates is so low that they cannot satisfy increased need in this acid.

Microbiological production of ICA could be a promising alternative to chemical synthesis and recovery from plants. ICA is produced by Yarrowia lipolytica yeast when its growth is limited by biogenic elements, in particular, nitrogen source [14-22]. In these processes, $n$-alcanes and plant oils are usually used as carbon substrates, and Y. lipolytica produces ICA and byproduct, citric acid (CA), in approximately equal amounts. It should be emphasized that $Y$. lipolytica yeasts as well as ICA are generally recognized as safe (GRAS) [12, 20].

At present, the ethanol is considered to be a promising carbon source in various biotechnological processes, because it can be produced from sugarcane, beet, corn, lignocellulose, and other renewable materials. Ethanol as a substrate for growth has several advantages over other substrates. It does not contain harmful impurities; it is well assimilated by yeast and dissolves in water in any proportions. Since ethanol is used in the human diet, the products derived from it do not require additional purification from the residual substrate. Several companies in the US and Switzerland have created food products based on microbial biomass produced from ethanol $[24,25]$. It should be noted that the large-scale production of ICA from ethanol is still limited by the lack of basic knowledge about fermentation conditions conducive to product overproduction.

The aim of this work was to study the effects of fermentation parameters (temperature, $\mathrm{pH}$, and aeration) and components of nutrition medium (zinc, iron, and itaconic acid) on the growth and ICA synthesis by Y. lipolytica grown on ethanol.

\section{Materials and Methods}

2.1. Chemicals. All chemicals were of analytical grade (Mosreactiv, Russia). Ethanol was purchased from "Kupavnareaktiv" (Russia).

2.2. Microorganism Used. Experiments were carried out with the yeast strain Y. lipolytica VKM Y-2373, which is able to produce ICA in marked amounts [19]. The strain was maintained at $+4^{\circ} \mathrm{C}$ on agar with paraffin.

2.3. The Determination of Cultivation Conditions. To determine the effect of temperature, $\mathrm{pH}$, and aeration on growth of Y. lipolytica VKM Y-2373, the yeast was cultivated in an ANKUM-2M fermenter with a 1.5-1 working volume of the medium containing $(\mathrm{g} / \mathrm{L})\left(\mathrm{NH}_{4}\right)_{2} \mathrm{SO}_{4}, 0.126 ; \mathrm{K}_{2} \mathrm{HPO}_{4}, 0.875$; MgSO $4{ }_{7} \mathrm{H}_{2} \mathrm{O}, 1.5 ; \mathrm{Ca}\left(\mathrm{NO}_{3}\right)_{2} \cdot 4 \mathrm{H}_{2} \mathrm{O}, 0.136 ; \mathrm{NaCl}, 0.5$; double Burkholder's trace element solution; yeast autolysate, $8 \mathrm{ml} / \mathrm{L}$. For preparation of yeast autolysate $10 \mathrm{~kg}$ of the commercial press baker's yeast (Saf-Neva, Ltd., Russia) was suspended in $6 \mathrm{~L}$ of distilled water. Autolysis was performed in the presence of 250 microliters of ethanol and 80 microliters of chloroform at $50^{\circ} \mathrm{C}$ during $24 \mathrm{~h}$. Then sample was centrifuged at $11000 \mathrm{~g}$ for $20 \mathrm{~min}$ at $4^{\circ} \mathrm{C}$ in order to remove cell debris. Amino nitrogen content in yeast autolysate consisted of $0.45 \%$. Ethanol was added by portions $(2 \mathrm{~g} / \mathrm{L})$ up to $10 \mathrm{~g} / \mathrm{L}$. The temperature, $\mathrm{pH}$, and the concentration of dissolved oxygen in the medium were maintained at a specified level as described in the Results and Discussion.

To determine the effect of fermentation parameters on ICA production, the yeast was cultivated in a $10 \mathrm{~L}$ ANKUM$2 \mathrm{M}$ fermenter (Russia) with $5 \mathrm{~L}$ of the medium (initial volume) containing (g/L) $\left(\mathrm{NH}_{4}\right)_{2} \mathrm{SO}_{4}, 3.0 ; \mathrm{KH}_{2} \mathrm{PO}_{4}, 2.0$; $\mathrm{K}_{2} \mathrm{HPO}_{4}, 0.2 ; \mathrm{MgSO}_{4} \cdot 7 \mathrm{H}_{2} \mathrm{O}, 1.4 ; \mathrm{Ca}\left(\mathrm{NO}_{3}\right)_{2} \cdot 4 \mathrm{H}_{2} \mathrm{O}, 0.8 ; \mathrm{NaCl}$, 0.5 ; Burkholder's trace element solution; yeast autolysate, $8 \mathrm{ml} / \mathrm{L}$. Pulsed additions of ethanol (by 2-6g/L) were performed as the $\mathrm{pO}_{2}$ value changed by $10 \%$ indicating a decrease in respiratory activity of cells due to the total consumption of the carbon source. During growth phase (up to $24 \mathrm{~h}$ ), the fermentation conditions were maintained automatically at the constant level: temperature $29 \pm 0.5^{\circ} \mathrm{C}$; $\mathrm{pH}$ of $5 \pm 0.1, \mathrm{pO}_{2}$ of $20-25 \%$ (of saturation); agitation $800 \mathrm{rpm}$. During acid formation phase (after $24 \mathrm{~h}$ ), $\mathrm{pH}$ and $\mathrm{pO}_{2}$ values in the medium were maintained as described in the Results and Discussion. Cultivation was carried out for 6 days.

To determine the optimal concentrations of zinc and iron ions for ICA production, the strain was grown in a fermenter under nitrogen limitation to the phase of active acid formation (biomass of $10-11 \mathrm{~g} / \mathrm{L}$ ). Cells were separated from the culture liquid by centrifugation, washed with $0.9 \% \mathrm{NaCl}$, and suspended in $50 \mathrm{mM}$ phosphate buffer $(\mathrm{pH} 7.0)$. The cell suspension was placed in 750-ml Erlenmeyer flasks with $50 \mathrm{ml}$ of the medium, which was free of nitrogen, microelements, and vitamins but contained ethanol (up to $10 \mathrm{~g} / \mathrm{L}$ ) and incubated on a shaker $(180-200 \mathrm{rpm})$ at $29^{\circ} \mathrm{C}$ for $36 \mathrm{~h}$. By the end of the experiment, $\mathrm{pH}$ of the medium slightly decreased (by 0.4-0.5 units), biomass remained at a constant level of $2.5 \mathrm{~g} / \mathrm{L}$, and the cell viability remained unchanged. The determination of the number of viable cells was carried out by inoculating on agar nutrient media with glucose as a carbon source.

To determine the optimal concentration of itaconic acid, the strain was grown at $29^{\circ} \mathrm{C}$ and various $\mathrm{pH}$ and $\mathrm{pO}_{2}$ values ( $\mathrm{pH} 5$ and $\mathrm{pO}_{2}$ of $20-25 \%$ during the growth period and $\mathrm{pH}$ 6 and $\mathrm{pO}_{2}$ of $50-55 \%$ during the acid formation period) on a nutrient medium containing increased $\mathrm{Zn}^{2+}(0.6 \mathrm{mg} / \mathrm{L})$ and $\mathrm{Fe}^{2+}(1.2 \mathrm{mg} / \mathrm{L})$. 


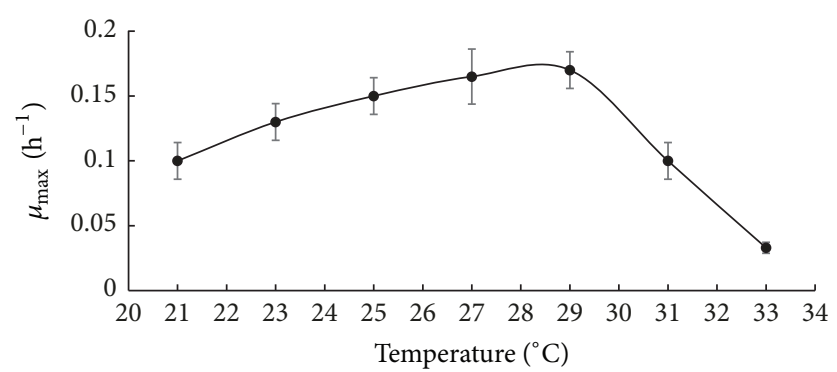

(a)

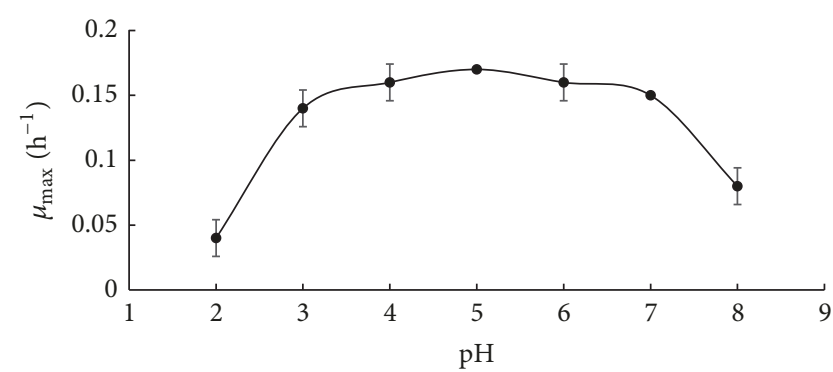

(b)

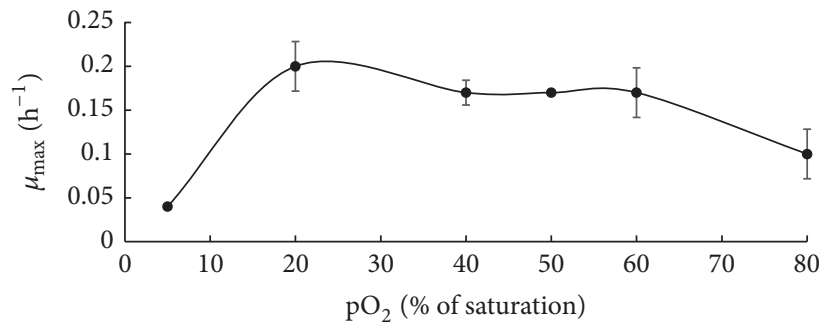

(c)

FIGURE 1: The effect of fermentation parameters ((a) temperature, (b) $\mathrm{pH}$ medium, and (c) $\mathrm{pO}_{2}$ (of saturation) on the maximal specific growth rate $\left.\left(\mu_{\max }\right)\right)$.

2.4. Calculation of Fermentation Parameters. In $\mathrm{pH}$-auxostat, the maximum specific growth rate $\left(\mu_{\max }\right)$ is equal to the dilution rate $D$.

Methods for calculation of mass yield coefficient of ICA production $\left(Y_{\mathrm{ICA}}\right)$ and the specific rate of ICA production $\left(q_{\text {ICA }}\right)$ were described earlier [19].

2.5. Measurement Techniques. Methods of analysis of nitrogen, biomass, ICA, and CA were described earlier [19].

\section{Results and Discussion}

3.1. Effect of Fermentation Parameters on the Growth and ICA Production. In order to select the optimal conditions for growth of Y. lipolytica VKM Y-2373, the effect of temperature, $\mathrm{pH}$, and aeration was studied under conditions of $\mathrm{pH}$ auxostat. Method of $\mathrm{pH}$-auxostat is a variant of the method of continuous cultivation of microorganisms, in which medium serves as titrant and is added to a fermenter according to a signal of $\mathrm{pH}$-meter, when $\mathrm{pH}$ of the culture liquid in a fermenter was changed from the established value. Under steady-state regime, all components of the medium in a fermenter are in excess, and microbial cells grow practically at the maximal specific growth rate $\left(\mu_{\max }\right)$, which is equal to the dilution rate of the medium. This method made it possible to study the effect of physical and chemical factors on $\mu_{\max }$ [26]. The data on the effect of temperature, $\mathrm{pH}$, and aeration on $\mu_{\max }$ are given in Figure 1 .

In experiments on the effect of temperature, the strain was grown at $\mathrm{pH}$ of 5 . The temperature was first decreased from 27 to 25,23 , and $21^{\circ} \mathrm{C}$, elevated to the initial level $\left(27^{\circ} \mathrm{C}\right)$, and then raised to 29,31 , and $33^{\circ} \mathrm{C}$. As seen from Figure 1, the optimal temperature for yeast growth was $29^{\circ} \mathrm{C}\left(\mu_{\max }\right.$ was $\left.0.17 \mathrm{~h}^{-1}\right)$.
When the temperature was lowered to $21^{\circ} \mathrm{C}$, the $\mu_{\max }$ value gradually decreased to $0.1 \mathrm{~h}^{-1}$. Elevation of the temperature from 29 to $33^{\circ} \mathrm{C}$ caused a decrease in the yeast growth 5.7 times.

The effect of $\mathrm{pH}$ on the $\mu_{\max }$ was studied at $29^{\circ} \mathrm{C}$; the concentration of dissolved oxygen was maintained at the constant level ( $\mathrm{pO}_{2}=60 \%$ of saturation). As seen in Figure 1, the optimal $\mathrm{pH}$ medium for yeast growth was $5.0\left(\mu_{\max }\right.$ was $\left.0.17 \mathrm{~h}^{-1}\right)$. Over the $\mathrm{pH}$ range from 7 to 3 , the $\mu_{\max }$ remained at a high level $\left(0.14-0.15 \mathrm{~h}^{-1}\right)$. When $\mathrm{pH}$ dropped below 3, yeast growth was strongly inhibited, and, at $\mathrm{pH} 2$, the $\mu_{\max }$ value was as low as $0.04 \mathrm{~h}^{-1}$. When $\mathrm{pH}$ raised to 8 , yeast growth was also inhibited, and, at $\mathrm{pH} 8$, the $\mu_{\max }$ value was $0.08 \mathrm{~h}^{-1}$.

The effect of oxygen concentration on the $\mu_{\max }$ value in the range from 5 to $80 \%$ (of saturation) was studied at $29^{\circ} \mathrm{C}$ and $\mathrm{pH}$ 5. As seen in Figure 1 , the optimal oxygen concentration for yeast growth was $20 \%$ (of saturation) ( $\mu_{\max }$ was $0.20 \mathrm{~h}^{-1}$ ). Over the $\mathrm{pO}_{2}$ range from 40 to $60 \%$ (of saturation), the $\mu_{\max }$ remained as a high level $\left(0.17-0.18 \mathrm{~h}^{-1}\right)$. The $\mu_{\max }$ value decreased by 2 times at oxygen concentration of $80 \%$ (of saturation). The extremely low aeration (5\% (of saturation)) limited growth $\left(\mu_{\max }\right.$ was $\left.0.04 \mathrm{~h}^{-1}\right)$ and induced the formation of pseudomycelial forms instead of rounded single cells observed at oxygen concentration of $20-60 \%$ (of saturation).

In order to select the optimal fermentation conditions for ICA production of Y. lipolytica VKM Y-2373, the effect of $\mathrm{pH}$ and aeration was studied under conditions of nitrogen limitation of growth in fed-batch mode. Ethanol creates certain difficulties during cultivation of microorganisms due to its toxicity. High concentrations of ethanol inhibit the cell growth and the transport of various nutrients and alter the permeability of the cytoplasmic membrane [27]. In 
TABLE 1: The effect of cultivation parameters on ICA production by Y. lipolytica.

\begin{tabular}{|c|c|c|c|c|c|}
\hline Parameters & Biomass $(\mathrm{g} / \mathrm{L})$ & ICA $(\mathrm{g} / \mathrm{L})$ & $\mathrm{CA}(\mathrm{g} / \mathrm{L})$ & ICA/CA ratio & $Y_{\text {ICA }}(\mathrm{g} / \mathrm{g})$ \\
\hline \multicolumn{6}{|c|}{$\mathrm{pH}^{1}$} \\
\hline 3 & $8.9 \pm 1.4$ & $13.75 \pm 2.14$ & $13.89 \pm 0.74$ & $1: 1$ & 0.13 \\
\hline 4 & $10.2 \pm 1.6$ & $20.81 \pm 3.24$ & $23.11 \pm 0.65$ & $1: 1.1$ & 0.21 \\
\hline 4.5 & $11.2 \pm 1.7$ & $37.12 \pm 2.67$ & $40.15 \pm 1.93$ & $1: 1.1$ & 0.35 \\
\hline 5 & $10.8 \pm 1.6$ & $40.64 \pm 1.92$ & $37.90 \pm 1.54$ & $1.1: 1$ & 0.38 \\
\hline 5.5 & $10.8 \pm 0.3$ & $50.55 \pm 0.64$ & $38.14 \pm 4.05$ & $1.3: 1$ & 0.47 \\
\hline 6 & $11.0 \pm 0.3$ & $59.00 \pm 3.52$ & $30.60 \pm 6.77$ & $1.9: 1$ & 0.55 \\
\hline 6.5 & $10.1 \pm 0.2$ & $48.50 \pm 3.54$ & $28.20 \pm 0$ & $1.7: 1$ & 0.48 \\
\hline 7 & $8.1 \pm 1.3$ & $12.33 \pm 1.98$ & $12.10 \pm 1.89$ & $1: 1$ & 0.17 \\
\hline \multicolumn{6}{|c|}{ Oxygen concentration (\% from saturation $)^{2}$} \\
\hline $5-10$ & $7.6 \pm 1.2$ & $4.3 \pm 0.6$ & $4.1 \pm 0.42$ & $1: 1$ & 0.10 \\
\hline $20-25$ & $10.3 \pm 1.6$ & $35 \pm 5.44$ & $21 \pm 3.27$ & $1.7: 1$ & 0.33 \\
\hline $30-35$ & $10.7 \pm 1.7$ & $53.2 \pm 8.27$ & $28 \pm 1.53$ & $1.9: 1$ & 0.50 \\
\hline $40-45$ & $11.2 \pm 1.8$ & $53.68 \pm 8.36$ & $27 \pm 1.37$ & $2: 1$ & 0.52 \\
\hline $50-55$ & $11.0 \pm 0.3$ & $59.0 \pm 3.52$ & $29.0 \pm 0.27$ & $2: 1$ & 0.55 \\
\hline $60-65$ & $10.4 \pm 1.6$ & $46.5 \pm 7.23$ & $24.5 \pm 0.43$ & $1.9: 1$ & 0.53 \\
\hline $75-80$ & $9.0 \pm 1.4$ & $35.3 \pm 5.49$ & $19.6 \pm 1.63$ & $1.8: 1$ & 0.45 \\
\hline
\end{tabular}

${ }^{1}$ The experiments were performed at $29^{\circ} \mathrm{C}$ and dissolved oxygen concentration $\left(\mathrm{pO}_{2}\right) 50 \%$ (of saturation); ${ }^{2}$ the experiments were performed at $29^{\circ} \mathrm{C}$ and $\mathrm{pH}$ 6 ; values are mean \pm standard deviation $(n=2)$.

this connection, the initial concentration of ethanol in the medium was $2 \mathrm{~g} / \mathrm{L}$. When $\mathrm{pO}_{2}$ in the medium exceeded its normal level by $10 \%$ (this increase in the concentration of dissolved oxygen in the medium indicated a reduction in the respiratory activity of yeast cells due to ethanol consumption), ethanol was replenished by the addition of a new portion of this nutrient in an amount corresponding to its concentration of $2-6 \mathrm{~g} / \mathrm{L}$ in the cultivation medium. The obtained data are shown in Table 1.

The effect of $\mathrm{pH}$ in the range from 3 to 7 on ICA production from ethanol was studied at $29^{\circ} \mathrm{C}$ and dissolved oxygen concentration $\left(\mathrm{pO}_{2}\right)$ of $50 \%$ (of saturation). As seen from Table 1, the maximum ICA production $(59.0 \mathrm{~g} / \mathrm{L})$ was observed at $\mathrm{pH} 6$; in this case, a ratio between ICA and CA amounted to $1.9: 1$, and product yield ( $\left.Y_{\text {ICA }}\right)$ achieved $0.55 \mathrm{~g} / \mathrm{g}$. When $\mathrm{pH}$ was lowered to 3 , ICA production gradually decreased to $13.75 \mathrm{~g} / \mathrm{L}$. Elevation of $\mathrm{pH}$ from 6 to 7 caused a decrease in ICA production 4.8 times. It should be noted that at $\mathrm{pH} 3, \mathrm{pH}$ 4, and $\mathrm{pH} 4.5$ Y. lipolytica VKM Y-2373 produced equal amounts of ICA and CA.

The effect of $\mathrm{pO}_{2}$ on ICA production in the range from $5-10$ to $75-80 \%$ was studied at $29^{\circ} \mathrm{C}$ and $\mathrm{pH}$ 6.0. As seen from Table 1, the maximum ICA production $(59.0 \mathrm{~g} / \mathrm{L})$ was $50-55 \%$ (of saturation); in this case, a ratio between ICA and CA amounted to $2: 1$, and product yield $\left(Y_{\text {ICA }}\right)$ achieved $0.55 \mathrm{~g} / \mathrm{g}$. The intensive ICA production was also observed at $\mathrm{pO}_{2}$ $30-35,40-45 \%$, and $60-65 \%$ (of saturation) and decreased by 1.7 times at oxygen concentrations $20-25$ and $70-80 \%$ (of saturation). The extremely low aeration (5-10\%) inhibited ICA production.

Therefore, it can be recommended to maintain $\mathrm{pH}$ and $\mathrm{pO}_{2}$ at the levels of 5.0 and $20 \%$ (of saturation), respectively, in the exponential phase for optimal culture growth and then to adjust $\mathrm{pH}$ to 6.0 and $\mathrm{pO}_{2}$ to $50-55 \%$ (of saturation) in the stationary phase for active ICA production by $Y$. lipolytica VKM Y-2373.

Literature data on the effect of temperature on physiology of Y. lipolytica are scarce. It is noted that temperature must be very well defined and optimized depending on the strain and the growth phase of producer. It was reported that Y. lipolytica grow well at temperatures between 20 and $37^{\circ} \mathrm{C}$ [28]. Moeller et al. (2007) found that, during Y. lipolytica growth, the temperature optimum was in the range of $30-34^{\circ} \mathrm{C}\left(\mu_{\max }=\right.$ $\left.0.132 \mathrm{~h}^{-1}\right)$, but the highest concentration of CA was obtained at $30^{\circ} \mathrm{C}\left(41 \mathrm{~g} / \mathrm{L} \mathrm{CA}\right.$ and product yield $\left(Y_{\mathrm{CA}}\right)$ of $\left.0.55 \mathrm{~g} / \mathrm{g}\right)$ [29]. Anastassiadis et al. (2002) reported the temperature optimum for CA production to be $30-31^{\circ} \mathrm{C}$ for Candida oleophila [30]. The authors of the last article explain this effect by stating that temperature influences regulation and transport systems of metabolites. The concentration of intracellular ICA decreased sharply with raising temperature and consequently the velocity of active transport system in C. oleophila, while intracellular CA concentration remained approximately constant; a higher intracellular CA/ICA ratio is to be recorded at higher temperatures, in contrary to an almost identical extracellular ratio.

It is known from the literature that variation of oxygen within the physiological range for Y. lipolytica yeast significantly influences the growth and acid formation. As noted, Y. lipolytica is an obligatory aerobe and does not grow without oxygen $[11,12]$. The dissolved oxygen concentration is considered as the major factor affecting yeast morphology. Specifically, when growth occurred at low or zero $\mathrm{pO}_{2}$ the mycelial and/or pseudomycelial forms predominated over the yeast form independently of the carbon and nitrogen sources used [31]. For Y. lipolytica, grown on fatty materials, 


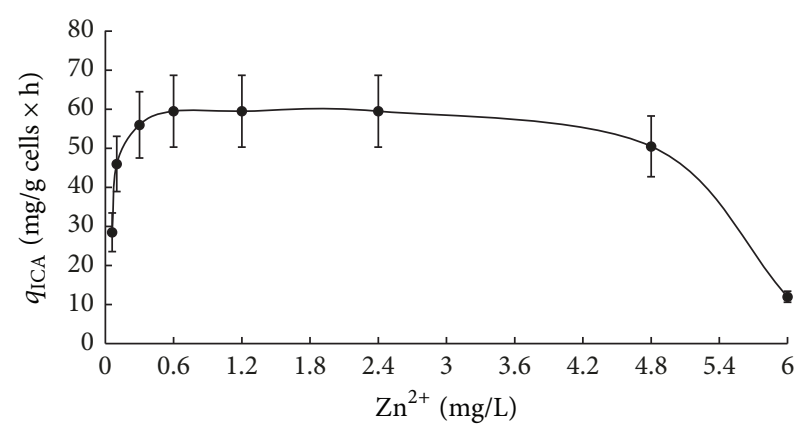

(a)

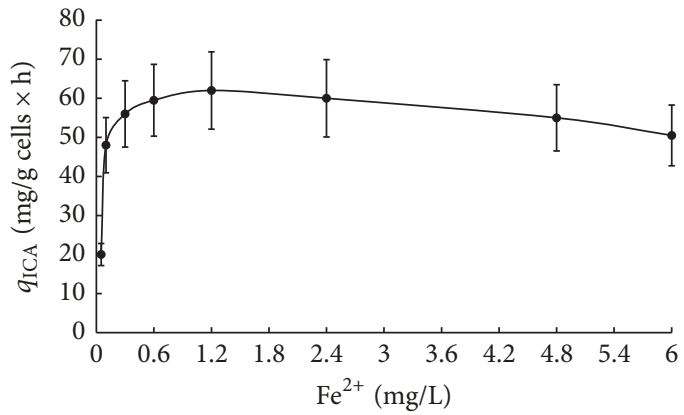

(b)

FIGURE 2: The effect of microelements ((a) zinc, (b) iron) on the specific rate of ICA production $\left(q_{\mathrm{ICA}}\right)$.

the good growth and the CA and ICA production were observed at an elevated level of dissolved oxygen, while the dissolved oxygen level close to zero led to the accumulation of intracellular lipids and extracellular lipase [32, 33]. For Y. lipolytica, cultivated on waste glycerol-based media under conditions of limitation of growth by nitrogen, with a high level of $\mathrm{pO}_{2}$, the metabolism shifted toward the formation of polyols, while at a low $\mathrm{pO}_{2}$ level, the nitrogen deficiency led to CA production [34].

Literature data on the effect of $\mathrm{pH}$ medium on physiology of Y. lipolytica are scarce. Moeller et al. (2007) found that the highest value of $\mu_{\max }\left(0.192 \mathrm{~h}^{-1}\right)$ was at $\mathrm{pH} 6.5$, whereas the largest amount of CA $(24.91 \mathrm{~g} / \mathrm{L})$, the highest selectivity of the process $(89.9 \% \mathrm{CA})$, and the maximum yield $\left(Y_{\mathrm{CA}}\right)(0.22 \mathrm{~g} / \mathrm{g})$ were obtained at $\mathrm{pH} 6.0$ [29]. It was reported that Y. lipolytica grows perfectly well over a wide $\mathrm{pH}$ range, but $\mathrm{pH}$ has a decisive influence on the metabolite pattern accumulated by this yeast. It was reported that Y. lipolytica is able to shift its metabolite pattern from polyol production at $\mathrm{pH} 3.5$ toward $\mathrm{CA}$ and ICA production at $\mathrm{pH} 5.5[35,36]$. Recently we found that ICA production from rapeseed oil and the ratio between ICA and CA depended on $\mathrm{pH}$ of the medium: $Y$. lipolytica produced predominantly ICA at $\mathrm{pH}$ 6.0, while equal amounts of ICA and CA were accumulated at pH 4.5 [19]. We suggested that $\mathrm{pH}$ showed no direct effect on mechanism of ICA synthesis but influenced considerably the permeability of cell membranes to both substrate and products.

3.2. Effects of Zinc and Iron. Earlier, we reported that zinc and iron play a key role in metabolism of Y. lipolytica. In particular, zinc limitation resulted in imbalance between the enzyme systems involved in primary ethanol oxidation, namely, alcohol dehydrogenase (EC 1.1.1.1) and aldehyde dehydrogenase (EC 1.2.1.3), which seemed to impose the accumulation of acetaldehyde, considered to be toxic for all cell functions [37, 38]. A relationship was found between the amount of $\mathrm{Fe}^{2+}$ and ICA production in Y. lipolytica grown on rapeseed oil, and, hence, we were successful in controlling the ICA/CA ration through the regulation of the iron-dependent enzyme aconitate hydratase (EC 4.2.1.1) by changing iron concentration in the medium [19].

In this study, the effects of zinc and iron concentrations on specific rate of ICA production (expressed in $\mathrm{mg} / \mathrm{g}$ cells $\times \mathrm{h}$ ) of the producer Y. lipolytica VKM Y-2373 were studied within the ranges $0.06-6 \mathrm{mg} / \mathrm{L}$ and $0.05-6 \mathrm{mg} / \mathrm{L}$, respectively. As seen from Figure 2, at low zinc level of $0.06 \mathrm{mg} / \mathrm{L} \mathrm{ICA}$ synthesis was insignificant. An increase in zinc from 0.06 to $0.6 \mathrm{mg} / \mathrm{L}$ caused an increase in ICA production 2 times, and the high specific rate of ICA production was maintained within the range $0.6-4.8 \mathrm{mg} / \mathrm{L}$. A further increase in zinc up to $6 \mathrm{mg} / \mathrm{L}$ imposed a sharp decrease in ICA production.

The effect of iron concentration $\left(\mathrm{Fe}^{2+}\right)$ on ICA production was studied at $\mathrm{Zn}^{2+}$ of $0.6 \mathrm{mg} / \mathrm{L}$. As seen from Figure $2, \mathrm{Fe}^{2+}$ of $0.05 \mathrm{mg} / \mathrm{L}$ limited ICA production. An increase in $\mathrm{Fe}^{2+}$ from 0.05 to $1.2 \mathrm{mg} / \mathrm{L}$ increased ICA 3.1 times, and a further increase in zinc up to $6 \mathrm{mg} / \mathrm{L}$ does not lead to suppression of ICA synthesis.

Thus, the highest ICA production by Y. lipolytica VKM Y-2373 grown on ethanol occurred at high concentrations of $\mathrm{Zn}^{2+}(0.6 \mathrm{mg} / \mathrm{L})$ and $\mathrm{Fe}^{2+}(1.2 \mathrm{mg} / \mathrm{L})$.

3.3. The Effect of Itaconic Acid on ICA Production. In the next experiments, we investigated the effect of itaconic acid on ICA production from ethanol by Y. lipolytica at high concentrations of $\mathrm{Zn}^{2+}(0.6 \mathrm{mg} / \mathrm{L})$ and $\mathrm{Fe}^{2+}(1.2 \mathrm{mg} / \mathrm{L})$. The itaconic acid was used at concentrations from 7.5 to $40 \mathrm{mM}$; it was added in a fermenter in the phase of growth retardation and beginning the accumulation of acids ( $24 \mathrm{~h}$ of cultivation). Data on the effect of itaconic acid on the ICA production by Y. lipolytica VKM Y-2373 are shown in Table 2. In control experiments, the yeast was cultivated without inhibitor.

As seen from Table 2, the addition of itaconic acid up to $30 \mathrm{mM}$ resulted in increase in ICA production from 64.3 to $72.19 \mathrm{~g} / \mathrm{L}$. Moreover, itaconic acid displaced the ratio of produced ICA to CA toward ICA. The maximum effect of itaconic acid was observed at its concentration of $30 \mathrm{mM}$ (ICA/CA $=4.1: 1$ as compared to $2.7: 1$ in the absence of the inhibitor). Thus, the addition of itaconic acid resulted in a $100 \%$ increase in ICA/CA ratio toward the ICA production. The product yield $\left(Y_{\text {ICA }}\right)$ achieved $0.77 \mathrm{~g} / \mathrm{g}$ at 20 and $30 \mathrm{mM}$ itaconic acid. At $40 \mathrm{mM}$ itaconic acid, ICA production and yield $\left(Y_{\text {ICA }}\right)$ were slightly decreased.

Earlier, the same correlation between itaconic acid and ICA production had been revealed when strain Y. lipolytica VKM Y-2373 was grown in the medium with rapeseed oil [22] and $n$-alkanes [39]. This phenomenon can be due to itaconic 
TABLE 2: The effect of itaconic acid on ICA production.

\begin{tabular}{|c|c|c|c|c|c|}
\hline Itaconic acid (мM) & Biomass $(\mathrm{g} / \mathrm{L})$ & ICA (g/L) & CA $(\mathrm{g} / \mathrm{L})$ & ICA/CA ratio & $Y_{\text {ICA }}(\mathrm{g} / \mathrm{g})$ \\
\hline 0 & $10.30 \pm 1.60$ & $64.30 \pm 7.18$ & $23.72 \pm 0.58$ & $2.7: 1$ & 0.60 \\
\hline 7.5 & $9.34 \pm 0.91$ & $61.78 \pm 14.46$ & $23.16 \pm 0.84$ & $2.7: 1$ & 0.65 \\
\hline 20 & $9.50 \pm 1.47$ & $69.61 \pm 7.63$ & $17.50 \pm 0.10$ & $4.0: 1$ & 0.77 \\
\hline 30 & $9.00 \pm 0.01$ & $72.19 \pm 2.73$ & $17.60 \pm 0.71$ & $4.1: 1$ & 0.77 \\
\hline 40 & $9.00 \pm 0.64$ & $68.00 \pm 3.51$ & $17.00 \pm 1.23$ & $4: 1$ & 0.68 \\
\hline
\end{tabular}

Values are mean \pm standard deviation $(n=2)$.

acid inhibition of isocitrate lyase (EC 4.1.3.1) (ICL), a key enzyme involved in the metabolism of ICA. Numerous studies confirmed that yeast ICL is a constitutive enzyme subject to catabolite repression. It is induced when the yeast grows on acetate, $n$-alkanes, ethanol, and fatty acids [4043]. At the same time, glucose in the cultivation medium suppresses ICL $[41,42]$. If the medium contains a mixture of hexadecane and glucose, ICL is suppressed until glucose is exhausted and then is induced providing the consumption of hexadecane [42]. The genetic studies of Saccharomyces cerevisiae showed that glucose suppresses ICL with the aid of ten amino acids inside the polypeptide chain with the involvement of the cAMP-dependent protein kinase [44]. The promoter region necessary for the activation of ICL synthesis is common to the genes encoding the enzymes involved in gluconeogenesis [45]. The deletion of the ICL1 gene from the genome of Y. lipolytica not only inhibits the assimilation of acetate, ethanol, and fatty acids but also reduces the rate of growth of this yeast on glucose [46]. The data available in the literature for yeasts show that 2phosphoenolpyruvate (PEP), 6-phosphogluconate, glucose 6-phosphate, pyruvate, and oxaloacetate are strong inhibitors of yeast ICL [47]. ICL is also inhibited by malate, fumarate, $\alpha$-ketoglutarate, and citrate [48]. It should be noted that all the aforementioned inhibitors are intermediates of the major metabolic pathways and, hence, cannot be considered as specific inhibitors of ICL in growing yeast cultures. The inhibitory action of itaconic acid (a structural analogue of succinate) is also well known $[22,39,49]$. Experiments with Y. lipolytica showed that itaconic acid specifically inhibits ICL and is not metabolized by the cells $[22,39]$. We reported that the addition of itaconic acid to the medium markedly inhibits ICL and, hence, reduces the amount of ICA cleaved by this enzyme [22]. This fact may well explain the displacement of ICA and CA formation toward the preferential synthesis of ICA, observed in the present study.

3.4. An Optimized Process of ICA Production. The optimized process of ICA production was carried out in a $10 \mathrm{~L}$ fermenter with a working volume of $5 \mathrm{~L}$ under optimal fermentation conditions ( $\mathrm{pH} 5$ and $\mathrm{pO}_{2} 20-25 \%$ (of saturation) during the growth and $\mathrm{pH} 6$ and $\mathrm{pO}_{2} 50-55 \%$ (of saturation) during acid formation) in a balanced nutrition medium $\left(\mathrm{Zn}^{2+} 0.6 \mathrm{mg} / \mathrm{L}\right.$, iron $1.2 \mathrm{mg} / \mathrm{L}$, and itaconic acid $30 \mathrm{mM}$ ).

Figure 3 shows the curves of growth of $Y$. lipolytica VKM Y-2373, nitrogen consumption, ICA production, and accumulation of byproduct of fermentation, CA. During the

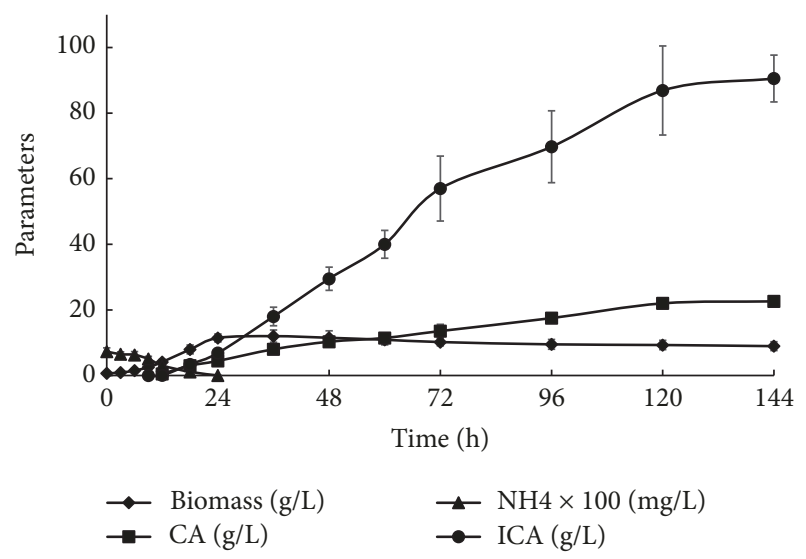

FIGURE 3: ICA production from ethanol of Y. lipolytica VKM Y-2373.

exponential growth phase (up to $6 \mathrm{~h}$ ), ICA did not accumulate. Its accumulation began in the growth retardation phase $(12-36 \mathrm{~h})$ and increased in the stationary phase (from $36 \mathrm{~h}$ ) caused by depletion of nitrogen in the medium. After $144 \mathrm{~h}$, the concentration of ICA in the medium reached $90.5 \mathrm{~g} / \mathrm{L}$ and $22.6 \mathrm{~g} / \mathrm{L}$ CA. The ratio of ICA/CA consisted of $4: 1$; therefore, the selectivity of fermentation was $80 \%$. The mass yield of ICA $\left(Y_{\text {ICA }}\right)$ with consideration for medium dilution caused by the addition of $\mathrm{KOH}$ solution for $\mathrm{pH}$ stabilization during fermentation was calculated to be $0.77 \mathrm{~g} / \mathrm{g}$ consumed ethanol. The productivity from ethanol consisted of $1.15 \mathrm{~g} / \mathrm{l} \cdot \mathrm{h}$.

The processes of ICA production from various substrates by yeast $Y$. lipolytica are presented in Table 3. In experiments with mutant Y. lipolytica NMM-149 grown on $n$-alkanes the ICA concentration reached $85 \mathrm{~g} / \mathrm{L}$ with a yield of $1.23 \mathrm{~g} / \mathrm{g}$ and a ratio between ICA and CA of 5.3:1 [14]. ICA production has been reported for wild strain of Y. lipolytica growing on ethanol: concentration reached $66 \mathrm{~g} / \mathrm{L}$ with a yield of $0.66 \mathrm{~g} / \mathrm{g}$ and a ratio between ICA and CA of 2.1:1 [23]. Heretsch et al. (2008) obtained ICA concentration of $93 \mathrm{~g} / \mathrm{L}$ and CA concentration of $82.8 \mathrm{~g} / \mathrm{L}$, which are equivalent to a $1.1: 1$ ratio of ICA : CA and a yield of $0.65 \mathrm{~g} / \mathrm{g}$ [16]. We found that wild strain Y. lipolytica VKM Y-2373, grown on rapeseed oil in the presence of itaconic acid, produced $70.6 \mathrm{~g} / \mathrm{L}$ ICA with a yield of $0.82 \mathrm{~g} / \mathrm{g}$ and a ratio between ICA and CA of $3.2: 1$, and the mutant strain Y. lipolytica 704-UV4-A/NG50 grown on rapeseed oil produced $86 \mathrm{~g} / \mathrm{L}$ ICA with a yield of $0.95 \mathrm{~g} / \mathrm{g}$ and a ratio between ICA and CA of $4.3: 1$ [19]. The cultivation of another mutant Y. lipolytica UV/NG in a pilot industrial 
TABLE 3: Comparative data on the processes of ICA production with the use of Y. lipolytica.

\begin{tabular}{|c|c|c|c|c|c|c|c|}
\hline Strain & Substrate & ICA $(\mathrm{g} / \mathrm{L})$ & $\mathrm{CA}(\mathrm{g} / \mathrm{L})$ & ICA/CA ratio & Productivity $(\mathrm{g} / \mathrm{l} \cdot \mathrm{h})$ & $Y_{\text {ICA }}(\mathrm{g} / \mathrm{g})$ & References \\
\hline Y. lipolytica NMM-149 & n-Alkanes & 85.0 & 16 & $5.3: 1$ & n.d. & 1.23 & [17] \\
\hline Y. lipolytica 704 & Ethanol & 66.0 & 31 & $2.1: 1$ & n.d. & 0.66 & [23] \\
\hline Y. lipolytica EH59 & Sunflower oil & 93.0 & 82.3 & $1.1: 1$ & n.d. & 0.65 & [16] \\
\hline Y. lipolytica VKM Y-2373 & Rapeseed oil & 70.6 & 22.4 & $3.2: 1$ & 0.797 & 0.82 & [19] \\
\hline Y. lipolytica 704-UV4-A/NG50 & Rapeseed oil & 86.0 & 20.0 & $4.3: 1$ & 0.970 & 0.95 & [19] \\
\hline Y. lipolytica UV/NG & Rapeseed oil & 88.7 & 15.1 & $6: 1$ & n.d. & 0.90 & {$[21]$} \\
\hline Y. lipolytica VKM Y-2373 & Ethanol & 90.5 & 22.6 & $4: 1$ & 1.15 & 0.770 & The present study \\
\hline
\end{tabular}

fermenter in the presence of itaconic acid resulted in the production of $88.7 \mathrm{~g} / \mathrm{L}$ ICA with a yield of $0.90 \mathrm{~g} / \mathrm{g}$ and only $15.1 \mathrm{~g} / \mathrm{L}$ of CA, so that the ICA : CA ratio was $6: 1$ [21]. It should be noted that the productivity of $Y$. lipolytica grown on rapeseed oil varied from 0.797 to $0.970 \mathrm{~g} / \mathrm{l} \cdot \mathrm{h}$ [19] while the productivity of ethanol obtained in this study was higher $(1.15 \mathrm{~g} / \mathrm{l} \cdot \mathrm{h})$.

3.5. Calculation of Energy Yields of ICA ( $\eta I C A)$. Since carbon substrates possessed different energy capacities, it is inappropriate to compare the ICA mass yields from different substrates. It is more correct to compare the energy yields of ICA $\left(\eta_{\text {ICA }}\right)$ on different carbon sources.

We calculated the value of $\eta_{\text {ICA }}$ which estimates a fraction of energy content of the substrate, incorporated into ICA, on the basis of mass and energy balance theory [50, 51]. Quantities that characterize mass and energy balance of cell metabolism are based on the generalized unit of reductivity, "redoxon"; it means an electron that can be transferred to oxygen; a former variant of this unit was an available electron. By definition, $\eta_{\text {ICA }}$ of the product is a fraction of the total amount of substrate redoxons (available electrons), which is incorporated into the product.

The value of $\eta_{\text {ICA }}$ was calculated using elementary composition of ICA and ethanol:

$$
\eta_{\mathrm{ICA}}=\frac{\left(\gamma_{\mathrm{ICA}} \cdot \delta_{\mathrm{ICA}}\right)}{\left(\gamma_{\mathrm{S}} \cdot \delta_{\mathrm{S}}\right)} \cdot Y_{\mathrm{ICA}},
$$

where $\delta_{\mathrm{S}}$ and $\delta_{\text {ICA }}$ are mass fractions of carbon in ethanol (S) and ICA, respectively; $\gamma_{\mathrm{S}}$ and $\gamma_{\mathrm{ICA}}$ are reductance degree and the number of redoxons per 1 carbon atom of ethanol (S) and ICA, respectively.

For the substance (individual compound or a mixture) having the elementary composition of $\mathrm{CH}_{p} \mathrm{O}_{n} \mathrm{~N}_{q}$ the reductance degree $(\gamma)$ was calculated as follows:

$$
\gamma=4+p-2 n-3 q
$$

where 4 and $p$ are the numbers of redoxons of the carbon and hydrogen atoms, respectively; $n$ and $q$ are the numbers of redoxons that lost their energy when they were bound up with the oxygen and nitrogen atoms, respectively. The elementary composition of ICA is $\mathrm{C}_{6} \mathrm{H}_{8} \mathrm{O}_{7}$ or $\mathrm{CH}_{8 / 6} \mathrm{O}_{7 / 6}$ after the calculation per 1 carbon atom, from which the reductance degree $\left(\gamma_{\text {ICA }}\right)$ is $4+8 / 6-2 \cdot 7 / 6=3$. The mass fraction of carbon in the molecule of ICA $\left(\delta_{\text {ICA }}\right)$ is 0.375 . Therefore, the value of $\gamma_{\text {ICA }} \cdot \delta_{\text {ICA }}$ is 1.125. Correspondingly, the value of $\gamma_{\mathrm{S}} \cdot \delta_{\mathrm{S}}$ for ethanol is 3.12. Thus, the value of $\eta_{\text {ICA }}$ from ethanol can be calculated as $(1.125 / 3.12) \cdot Y_{\text {ICA }}$. Therefore, the value of $\eta_{\text {ICA }}$ Y. lipolytica VKM Y-2373, grown on ethanol, was $0.278 \mathrm{~g} / \mathrm{g}$.

In comparison, $\eta_{\mathrm{ICA}}$ for $Y$. lipolytica $704-\mathrm{UV} 4-\mathrm{A} / \mathrm{NG} 50$, grown on rapeseed oil, was calculated on the basis of the value of $Y_{\text {ICA }}$ of $0.95 \mathrm{~g} / \mathrm{g}$ [19]. Taking into account the fact that the value of $\gamma_{\text {ICA }} \cdot \delta_{\text {ICA }}$ comprised 1.125 and the value of $\gamma_{\mathrm{S}} \cdot \delta_{\mathrm{S}}$ for rapeseed oil, which contained mainly oleic acid, averaged to 4.28 , the value of $\eta_{\mathrm{ICA}}$ for rapeseed oil-grown Y. lipolytica 704-UV4-A/NG50 was calculated as $(1.125 / 4.28) \cdot 0.95=$ $0.250 \mathrm{~g} / \mathrm{g}$. Thus, the value of $\eta_{\text {ICA }}$ for ethanol-grown strain $Y$. lipolytica VKM Y-2373 ( $0.278 \mathrm{~g} / \mathrm{g})$ was comparable with that obtained with the best mutant strain Y. lipolytica, grown on rapeseed oil $(0.250 \mathrm{~g} / \mathrm{g})$.

\section{Conclusion}

Thus, it can be concluded that both fermentation conditions such as $\mathrm{pH}$ and aeration and the composition of medium (concentration of zinc, iron, and itaconic acid (inhibitor of ICL-the key enzyme of ICA metabolism)) are effective factors controlling the ICA synthesis in Y. lipolytica yeast, grown on ethanol. The cultivation of Y. lipolytica VKM Y2373 on a nutrient medium containing an increased content of zinc $(0.6 \mathrm{mg} / \mathrm{L})$, iron $(1.2 \mathrm{mg} / \mathrm{L})$, and $30 \mathrm{mM}$ itaconic acid under selected optimal conditions at $29^{\circ} \mathrm{C}$ and various $\mathrm{pH}$ of the medium and the oxygen concentration $\left(\mathrm{pH} 5\right.$ and $\mathrm{pO}_{2}$ $20-25 \%$ (of saturation) during the growth period and $\mathrm{pH} 6$ and $\mathrm{pO}_{2} 50-55 \%$ (of saturation) during the acid formation) ensured direct ICA production $(90.5 \mathrm{~g} / \mathrm{L}$; selectivity of $80 \%$; the mass yield of ICA $\left(Y_{\text {ICA }}\right) 0.77 \mathrm{~g} / \mathrm{g}$; and the energy yield of $\left.\operatorname{ICA}\left(\eta_{\mathrm{ICA}}\right) 0.278 \mathrm{~g} / \mathrm{g}\right)$

\section{Conflicts of Interest}

The authors have no conflicts of interest to declare.

\section{Acknowledgments}

This work was supported by Russian Foundation for Basic Research and Moscow Oblast [Grant no. 17-48-500446] and the Ministry of Education and Science of the Russian Federation (Agreement no. 02.a03.0008). 


\section{References}

[1] R. Stark and M. Roden, "Mitochondrial function and endocrine diseases," European Journal of Clinical Investigation, vol. 37, no. 4, pp. 236-248, 2007.

[2] A. Devin and M. Rigoulet, "Mechanisms of mitochondrial response to variations in energy demand in eukaryotic cells," American Journal of Physiology-Cell Physiology, vol. 292, no. 1, pp. C52-C58, 2007.

[3] M. Kondrashova, M. Zakharchenko, and N. Khunderyakova, "Preservation of the in vivo state of mitochondrial network for ex vivo physiological study of mitochondria," The International Journal of Biochemistry \& Cell Biology, vol. 41, no. 10, pp. 20362050, 2009 .

[4] W. W. Wheaton and N. S. Chandel, "Hypoxia. 2. Hypoxia regulates cellular metabolism," American Journal of PhysiologyCell Physiology, vol. 300, no. 3, pp. C385-C393, 2011.

[5] L. D. Lukyanova, "Mitochondrial signaling in hypoxia," Open Journal of Endocrine and Metabolic Diseases, vol. 3, no. 2, pp. 20-32, 2013.

[6] H. Kumar and D.-K. Choi, "Hypoxia Inducible Factor Pathway and Physiological Adaptation: A Cell Survival Pathway?" Mediators of Inflammation, vol. 2015, Article ID 584758, 11 pages, 2015.

[7] M. R. De Oliveira, N. Elangovan, M. Ljubkovic, and A. Baranova, "The roads to mitochondrial dysfunction," BioMed Research International, vol. 2015, Article ID 235370, 2 pages, 2015.

[8] J. Chow, J. Rahman, J. C. Achermann, M. T. Dattani, and S. Rahman, "Mitochondrial disease and endocrine dysfunction," Nature Reviews Endocrinology, vol. 13, no. 2, pp. 92-104, 2017.

[9] M. N. Kondrashova, M. V. Zakharchenko, N. V. Khunderiakova et al., "[State of succinate dehydrogenase in the organism"unbalanced" or hyperactive].," Biofizika, vol. 58, no. 1, pp. 106116, 2013.

[10] T. M. Carole, J. Pellegrino, and M. D. Paster, "Opportunities in the industrial biobased products industry," Applied Biochemistry and Biotechnology, vol. 115, no. 1-3, pp. 871-885, 2004.

[11] T. V. Finogenova, I. G. Morgunov, S. V. Kamzolova, and O. G. Chernyavskaya, "Organic acid production by the yeast Yarrowia lipolytica: A review of prospects," Applied Biochemistry and Microbiology, vol. 41, no. 5, pp. 418-425, 2005.

[12] S. S. Zinjarde, "Food-related applications of Yarrowia lipolytica," Food Chemistry, vol. 152, pp. 1-10, 2014.

[13] H. B. Vickery, "A suggested new nomenclature for the isomers of isocitric acid," The Journal of Biological Chemistry, vol. 237, pp. 1739-1741, 1962.

[14] T. V. Finogenova, N. V. Shishkanova, V. I. Illarionowa et al., "Strain Candida lipolytica NMM-149 as producer of isocitric acid," USSR Inventor's Certificate SU915466A1, dated 23.06.1989.

[15] A. Förster, K. Jacobs, T. Juretzek, S. Mauersberger, and G. Barth, "Overexpression of the ICL1 gene changes the product ratio of citric acid production by Yarrowia lipolytica," Applied Microbiology and Biotechnology, vol. 77, no. 4, pp. 861-869, 2007.

[16] P. Heretsch, F. Thomas, A. Aurich, H. Krautscheid, D. Sicker, and A. Giannis, "Syntheses with a chiral building block from the citric acid cycle: $(2 \mathrm{R}, 3 \mathrm{~S})$-isocitric acid by fermentation of sunflower oil," Angewandte Chemie International Edition, vol. 47, no. 10, pp. 1958-1960, 2008.

[17] M. Holz, A. Förster, S. Mauersberger, and G. Barth, "Aconitase overexpression changes the product ratio of citric acid production by Yarrowia lipolytica," Applied Microbiology and Biotechnology, vol. 81, no. 6, pp. 1087-1096, 2009.

[18] A. Aurich, R. Specht, R. A. Müller et al., "Microbiologically produced carboxylic acids used as building blocks in organic synthesis," in in Reprogramming Microbial Metabolic Pathways, X. Wang, J. Chen, and P. Quinn, Eds., vol. 64, pp. 391-423, Springer, Dordrecht, Netherlands, 2012.

[19] S. V. Kamzolova, E. G. Dedyukhina, V. A. Samoilenko et al., "Isocitric acid production from rapeseed oil by Yarrowia lipolytica yeast," Applied Microbiology and Biotechnology, vol. 97, no. 20, pp. 9133-9144, 2013.

[20] M. Groenewald, T. Boekhout, C. Neuvéglise, C. Gaillardin, P. W. M. Van Dijck, and M. Wyss, "Yarrowia lipolytica: Safety assessment of an oleaginous yeast with a great industrial potential," Critical Reviews in Microbiology, vol. 40, no. 3, pp. 187-206, 2014.

[21] S. V. Kamzolova, Y. N. Lunina, R. K. Allayarov et al., "Biosynthesis of isocitric acid by the yeast Yarrowia lipolytica and its regulation," Applied Biochemistry and Microbiology, vol. 51, no. 2, pp. 249-254, 2015.

[22] S. V. Kamzolova, R. K. Allayarov, J. N. Lunina, and I. G. Morgunov, "The effect of oxalic and itaconic acids on threoDs-isocitric acid production from rapeseed oil by Yarrowia lipolytica," Bioresource Technology, vol. 206, pp. 128-133, 2016.

[23] T. V. Finogenova, N. V. Shishkanova, E. A. Fausek, and S. S. Eremina, "Biosynthesis of isocitric acid from ethanol by yeasts," Applied Microbiology and Biotechnology, vol. 36, no. 2, pp. 231235, 1991.

[24] G. Stephanopoulos, "Challenges in engineering microbes for biofuels production," Science, vol. 315, no. 5813, pp. 801-804, 2007.

[25] R. A. Weusthuis, J. M. M. J. G. Aarts, and J. P. M. Sanders, "From biofuel to bioproduct: Is bioethanol a suitable fermentation feedstock for synthesis of bulk chemicals?" Biofuels, Bioproducts and Biorefining, vol. 5, no. 5, pp. 486-494, 2011.

[26] G. A. Martin and W. P. Hempfling, "A method for the regulation of microbial population density during continuous culture at high growth rates," Archives of Microbiology, vol. 107, no. 1, pp. 41-47, 1976.

[27] R. P. Jones, "Biological principles for the effects of ethanol," Enzyme and Microbial Technology, vol. 11, no. 3, pp. 130-153, 1989.

[28] S. Anastasssiadis, I. G. Morgunov, S. V. Kamzolova, and T. V. Finogenova, "Citric acid production patent review," Recent Patents on Biotechnology, vol. 2, no. 2, pp. 107-123, 2008.

[29] L. Moeller, B. Strehlitz, A. Aurich, A. Zehnsdort, and T. Bley, "Optimization of citric acid production from glucose by Yarrowia lipolytica," Engineering in Life Sciences, vol. 7, no. 5, pp. 504-511, 2007.

[30] S. Anastassiadis, A. Aivasidis, and C. Wandrey, "Citric acid production by Candida strains under intracellular nitrogen limitation," Applied Microbiology and Biotechnology, vol. 60, no. 1-2, pp. 81-87, 2002.

[31] S. Bellou, A. Makri, I.-E. Triantaphyllidou, S. Papanikolaou, and G. Aggelis, "Morphological and metabolic shifts of Yarrowia lipolytica induced by alteration of the dissolved oxygen concentration in the growth environment," Microbiology, vol. 160, no. 4, Article ID 074302, pp. 807-817, 2014.

[32] N. Bati, E. G. Hammond, and B. A. Glatz, "Biomodification of fats and oils: trials with Candida lipolytica," Journal of the American Oil Chemists' Society, vol. 61, no. 11, pp. 1743-1746, 1984. 
[33] S. Papanikolaou, I. Chevalot, M. Galiotou-Panayotou, M. Komaitis, I. Marc, and G. Aggelis, "Industrial derivative of tallow: a promising renewable substrate for microbial lipid, single-cell protein and lipase production by Yarrowia lipolytica," Electronic Journal of Biotechnology, vol. 10, no. 3, pp. 425-435, 2007.

[34] S. Papanikolaou, E. Kampisopoulou, F. Blanchard et al., "Production of secondary metabolites through glycerol fermentation under carbon-excess conditions by the yeasts Yarrowia lipolytica and Rhodosporidium toruloides," European Journal of Lipid Science and Technology, vol. 119, no. 9, Article ID 1600507, 2017.

[35] M. Rakicka, A. Rywińska, K. Cybulski, and W. Rymowicz, "Enhanced production of erythritol and mannitol by yarrowia lipolytica in media containing surfactants," Brazilian Journal of Microbiology, vol. 47, no. 2, pp. 417-423, 2016.

[36] M. Egermeier, H. Russmayer, M. Sauer, and H. Marx, "Metabolic flexibility of yarrowia lipolytica growing on glycerol," Frontiers in Microbiology, vol. 8, article no. 49, 2017.

[37] T. V. Finogenova, S. V. Kamzolova, E. G. Dedyukhina et al., "Biosynthesis of citric and isocitric acids from ethanol by mutant Yarrowia lipolytica N 1 under continuous cultivation," Applied Microbiology and Biotechnology, vol. 59, no. 4-5, pp. 493-500, 2002.

[38] S. V. Kamzolova, M. N. Chiglintseva, J. N. Lunina, and I. G. Morgunov, " $\alpha$-Ketoglutaric acid production by Yarrowia lipolytica and its regulation," Applied Microbiology and Biotechnology, vol. 96, no. 3, pp. 783-791, 2012.

[39] R. Karklin, I. Peltzmane, L. Raminya, and G. Korde, "Overproduction of isocitric acid by wild strain of Candida lipolytica," in Metabolism of $n$-Alkanes and Oversynthesis of Products by Microorganisms, T. V. Finogenova and A. A. Sharyshev, Eds., pp. 143-146, Scientific Center of the USSR Academy of Sciences, Pushchino, Russia, 1991.

[40] J. E. Holdsworth, M. Veenhuis, and C. Ratledge, "Enzyme activities in oleaginous yeasts accumulating and utilizing exogenous or endogenous lipids," Journal of General Microbiology, vol. 134, pp. 2907-2915, 1988.

[41] P. De Jong-Gubbels, P. Vanrolleghem, S. Heijnen, J. P. Van Dijken, and J. T. Pronk, "Regulation of carbon metabolism in chemostat cultures of Saccharomyces cerevisiae grown on mixtures of glucose and ethanol," Yeast, vol. 11, no. 5, pp. 407418, 1995.

[42] S. V. Kamzolova, J. N. Lunina, and I. G. Morgunov, "Biochemistry of citric acid production from rapeseed oil by Yarrowia lipolytica yeast," Journal of the American Oil Chemists' Society, vol. 88, no. 12, pp. 1965-1976, 2011.

[43] S. Papanikolaou and G. Aggelis, "Lipids of oleaginous yeasts. Part II: technology and potential applications," European Journal of Lipid Science and Technology, vol. 113, no. 8, pp. 1052-1073, 2011.

[44] I. Ordiz, P. Herrero, R. Rodicio, and F. Moreno, "Glucoseinduced inactivation of isocitrate lyase in Saccharomyces cerevisiae is mediated by the cAMP-dependent protein kinase catalytic subunits Tpk1 and Tpk2," FEBS Letters, vol. 385, no. 1-2, pp. 43-46, 1996.

[45] A. Schöler and H.-J. Schüller, "A carbon source-responsive promoter element necessary for activation of the isocitrate lyase gene ICL1 is common to genes of the gluconeogenic pathway in the yeast Saccharomyces cerevisiae," Molecular and Cellular Biology, vol. 14, no. 6, pp. 3613-3622, 1994.
[46] G. Barth and T. Scheuber, "Cloning of the isocitrate lyase gene (ICL1) from Yarrowia lipolytica and characterization of the deduced protein," MGG Molecular \& General Genetics, vol. 241, no. 3-4, pp. 422-430, 1993.

[47] W. Hildebrandt and H. Weide, "Isocitratlyase von Candida guilliermondii, Stamm H17. III. Regelung durch Intermediate des Alkanabbaus und allgemeines Regulationsmodell," Zeitschrift für Allgemeine Mikrobiologie, vol. 14, no. 1, pp. 47-52, 1974.

[48] A. T. Eprintsev, A. V. Salnikov, A. M. Haba, and M. V. Zaichikova, "Isocitrate lyase isozymes and their role in organisms with different levels of organization," Biology Bulletin Reviews, vol. 4, no. 4, pp. 323-334, 2014.

[49] M. Krátký and J. Vinšová, "Advances in mycobacterial isocitrate lyase targeting and inhibitors," Current Medicinal Chemistry, vol. 19, no. 36, pp. 6126-6137, 2012.

[50] I. G. Minkevich and V. K. Eroshin, "Productivity and heat generation of fermentation under oxygen limitation," Folia Microbiologica, vol. 18, no. 5, pp. 376-385, 1973.

[51] L. E. Erickson, I. G. Minkevich, and V. K. Eroshin, "Application of mass and energy balance regularities in fermentation," Biotechnology and Bioengineering, vol. 67, no. 6, pp. 748-774, 2000 . 


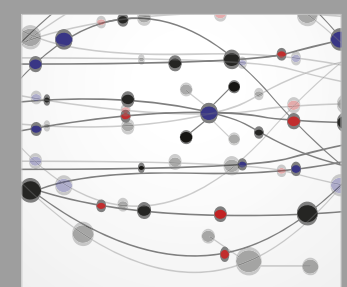

The Scientific World Journal
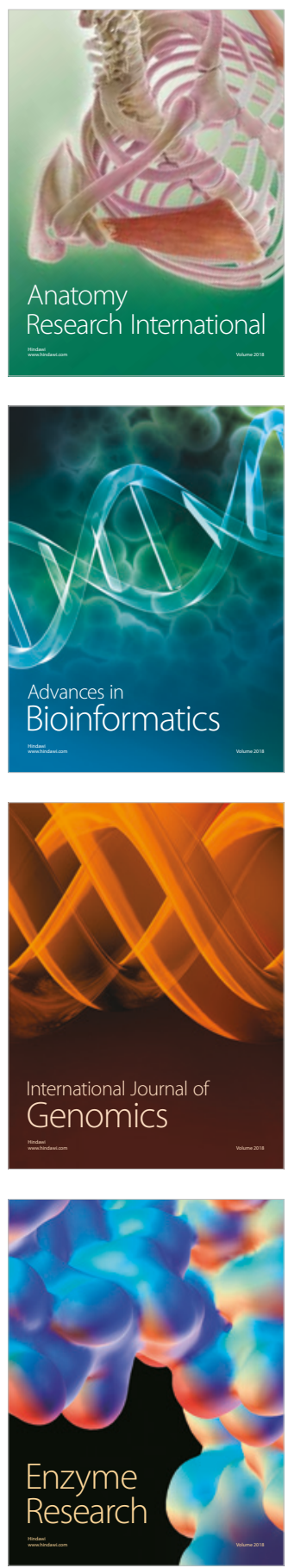
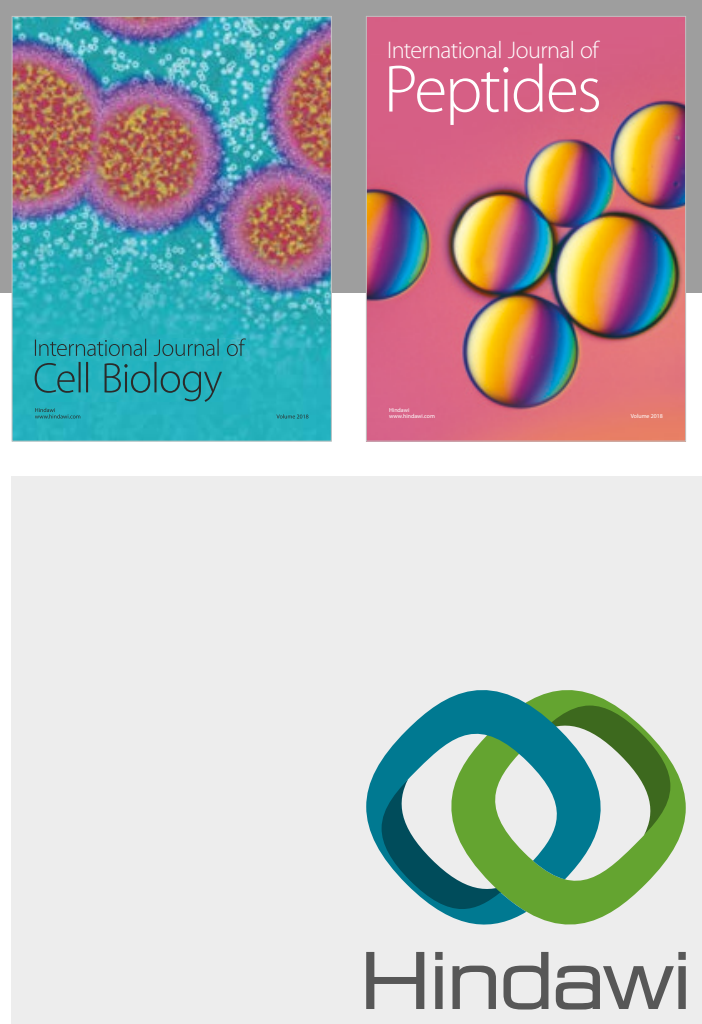

Submit your manuscripts at

www.hindawi.com
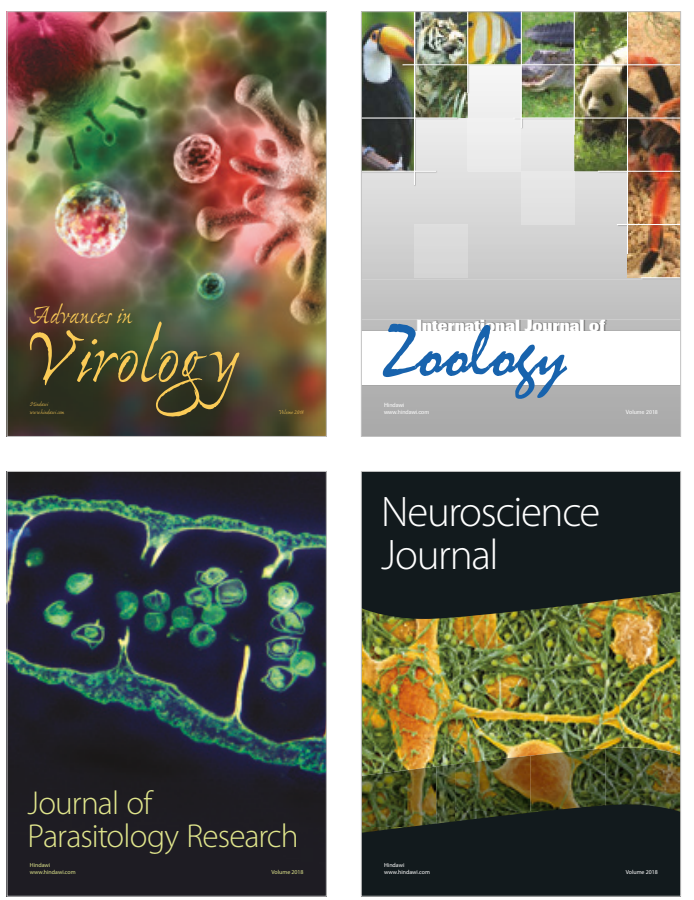
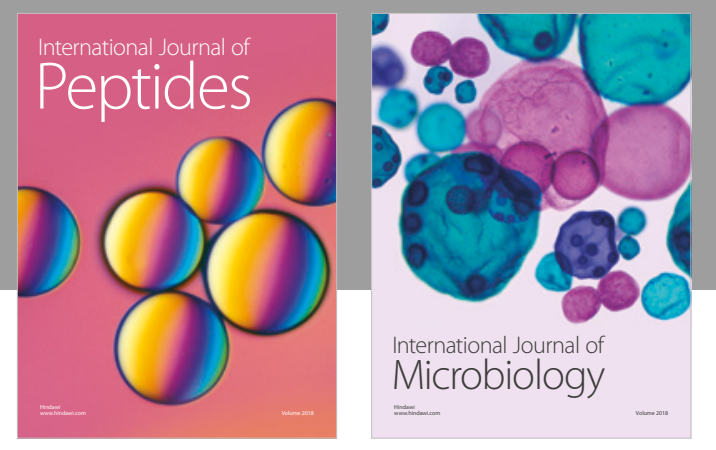

nternational Journal of Microbiology
Journal of
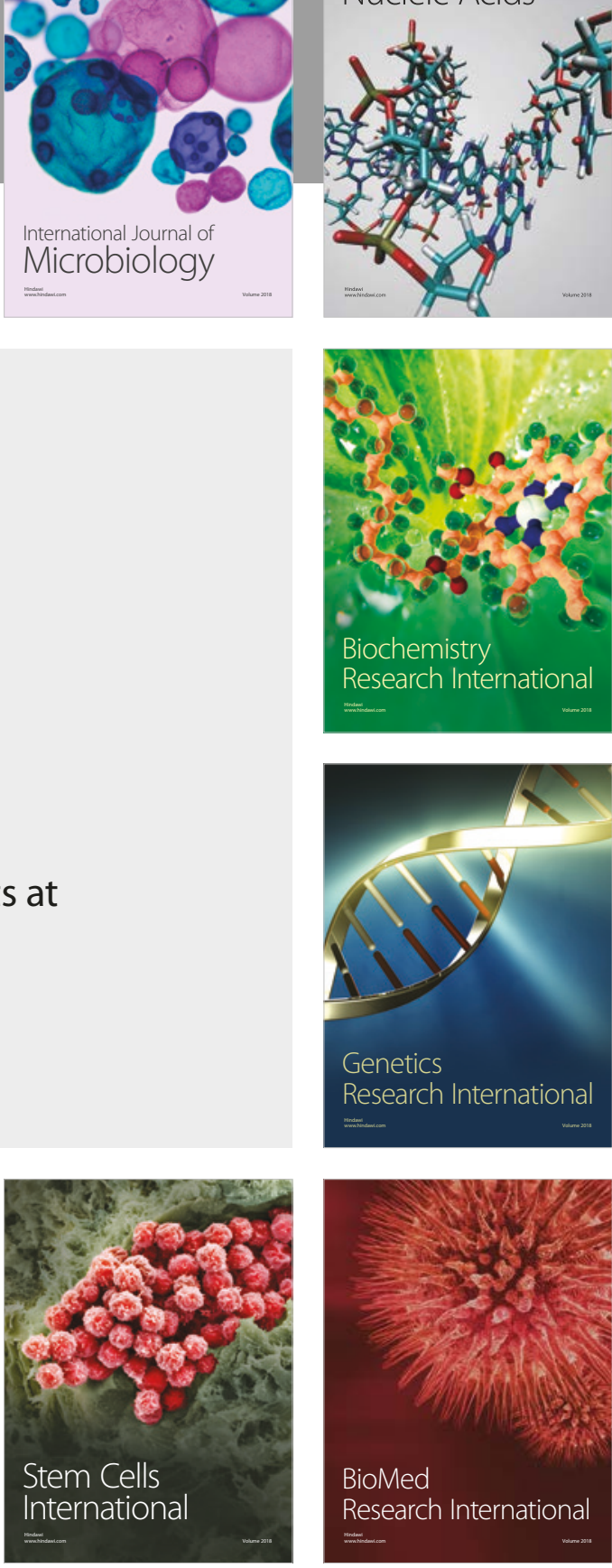
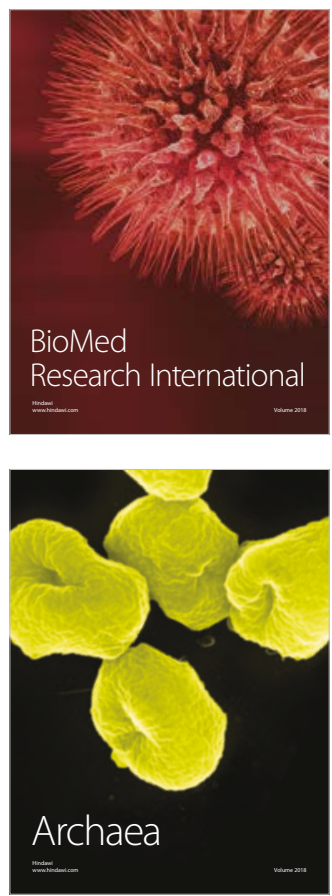